\title{
O diálogo segundo enunciadores incertos
}

\author{
Julie Sermon ${ }^{2}$
}

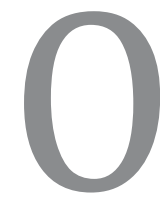

personagem teatral não escapou da "desconfiança" de nossa modernidade. Após a virada do século XX, foi despojado progressivamente de tudo que contribuía para fazer dele um indivíduo possível, no mínimo plausível, tal como postulava a ilusão mimética burguesa (ancoragem referencial, consciência estável e intencional, comportamento interpretável em termos de uma racionalidade psicológica), para finalmente aparecer como um dado relativamente acessório, no mínimo contingente, dentro das escritas dos últimos trinta anos. Os autores, tomando posição acerca do estado da crise diagnosticado por Robert Abirached ${ }^{3}$, acabaram por restringir-se unicamente ao teatro da palavra, e substituíram a exploração poética da enunciação pelo funcionamento teleológico do diálogo absoluto. ${ }^{4}$ A incerteza que estatuto do personagem está vinculada à desagregação do modelo aristotélico: na medida em que a ação não é mais a força propulsora do drama; em que a palavra não define mais necessariamente o caminho a seguir; em que o personagem se vê de fato privado da continuidade substancial e actancial de sua identidade, e vice-versa. Enquanto os enunciadores forem concebidos como agentes fabula-

\footnotetext{
1 Publicado sob o título "Le dialogue aux énonciateurs incertains", in: Ryngaert, JeanPierre et al. Nouveaux Territoires du Dialogue. Actes Sud Papiers/CNSAD 2005, p.31-35. Tradução: Stephan Baumgärtel e José Ronaldo Faleiro.

2 Julie Sermon é docente e pesquisadora da Universidade Lyon 2. Seus interesses de pesquisa são dramaturgias modernas e contemporâneas, textuais e cênicas; história e estética da encenação; a cena e as tecnologias, entre outros.

3 Abirached, Robert. La Crise du personnage dans le théâtre modern. Paris: Grasset, 1978.

4 Ryngaert, Jean-Pierre. Ler o teatro contemporâneo. São Paulo: Martins Fontes. 1999.
}

res $^{5}$, serão donos de sua palavra e formarão uma unidade com ela: imagem de sua identidade; afirmação de sua consciência e expressão de seus sentimentos, ela é precisamente aquilo que os constrói como "protagonistas". Dentro dos teatros nãoinstrumentalizados ${ }^{6}$ - aqueles que não são a priori direcionados à perseguição de uma intriga ou ao agenciamento de uma narrativa - os personagens, ao contrario, parecem [muitas vezes] ser muito mais atravessados pela palavra do que a carregarem ou do que serem a sua origem. Não são mais a condição necessária dos enunciados, que se desenvolvem segundo sua própria lógica, inventando suas próprias dramaturgias. O diálogo se constrói na margem, na contramão, às expensas dos interlocutores, cuja individualidade e autonomia tendem a se anular simultaneamente.

Dentro da continuidade das escritas do nouveau roman, certos autores abrem mão daqui para a frente de identidades fictícios definidas, para só se dedicar ao desafio do falar e da voz: os enunciadores então se veem investidos no papel mínimo de ser o polo de emissão, sem que as palavras que eles expõem construíssem algo da ordem de uma subjetividade. Esta exposição do abandono da suposta individualidade dos enunciadores cria espaço para uma dupla configuração.

A primeira consiste em expulsar a

\footnotetext{
5 No original fabulaires, um neologismo que combina fable, fabuleux e o sufixo aire, no sentido de definir uma qualidade: são pertentes ao mundo das fabulas, da fiç̧ão. [Nota do tradutor]

6

Parto da oposição estabelecida por Michel Vinaver nas quais "a palavra é instrumento da ação" e aquelas nas quais "a palavra é ação". In: VINAVER, Michel. Ecritures dramatiques. Essais d'analyse de textes de théâtre, Actes Sud, coll. Babel, 2000.
} 
própria noção do diálogo: os autores não propõem nada além de um tecido de vozes alternadamente justapostas, sincopizadas, entrelaçadas, que prosseguem essencialmente por meio de declinações, repetições e variações. Esse modelo privilegia a dimensão musical e rítmica da palavra e termina na maioria das vezes em uma forma de coralidade: todos os enunciadores participam de um mesmo movimento; contribuem para compor uma narrativa em forma de partitura, cujos efeitos de eco e de rupturas se referem somente à atividade poética de enunciação. $\mathrm{O}$ jogo e a virtuosidade técnica do ator têm a tendência de se sobrepor, parcial ou completamente, aos efeitos de ficção.

O segundo modelo não rejeita de modo tão radical a narração, mas já não torna os enunciadores responsáveis por isso: os autores inventam espécies de metadiálogos que fazem uso de elementos implícitos da enunciação e criam conflitos que são nada além de metalinguísticos. Os enunciadores se apresentam ao espectador menos como indivíduos do que como a encarnação de pequenas ilhas de palavras, de "tropismos", deixando-se seduzir pelo que Arnaud Rykner nomeia "logodrama".

Outra tendência de escrita contemporânea, que se inscreve sobretudo dentro de uma lógica de conversação, esvazia menos a noção de "personagem" do que inverte seus pressupostos tradicionais. No início da escrita, os autores se contentam com um tipo de grau zero do personagem: ele é um falador, um ser somente trançado pelas palavras que pronuncia - e não uma identidade tirada da própria realidade pelo tempo de uma representação. Se o personagem tradicional fala conforme aquilo que podemos esperar de seu perfil (psicológico, sociológico), as identidades assim postas em jogo se afirmam ao contrário cruamente, em sua essência teatral mínima: desprovidas de seus atributos substanciais ilusionistas, não são mais as avalistas, mas o efeito do diálogo que elas expõem - di-

7 RYKner, Arnaud. Théâtres du nouveau roman. Sarraute, Pinget, Duras. Paris: José Corti, 1988 álogo que obedece somente a sua própria lógica de gestação, a suas próprias necessidades poéticas, frequentemente contrárias aos pressupostos realistas, sem que seja, em todo caso, subordinado às intenções ou à vontade daqueles que o emitem. Terminamos em um tipo de inversão "logontológica": os enunciadores só se afirmam no decorrer e ao sabor das trocas [verbais]. É unicamente a singularidade de suas voltas e de sua construção que permite defini-las, mais ou menos exatamente/com exatidão, por um/num tempo mais ou menos longo.

Com isso, é evidente que a integridade ficcional dos enunciadores se encontra profundamente abalada: eles existem sem espessura e sem continuidade, pois tudo - seus estados, seus humores, suas reações -é submetido aos fluxos e refluxos da palavra, sem outra justificativa. Simultaneamente, as explorações na enunciação às quais as escritas se entregam também as fazem adquirir uma densidade e uma opacidade novas: se os enunciadores não se aparentam mais com simulacros de indivíduos que dividem um pedaço de existência ilusória, eles se impõem como seres de palavras, com singularidade irredutível, ao mesmo tempo barqueiro e parte interessada, em um universo que não existe antes de sua enunciação. Ao entregar aos sitcoms e a outros reality shows o privilégio de uma incessante dramatização das relações humanas (segundo esquemas cada vez mais formatados e diálogos cada vez mais gastos), bem como as identificações experimentadas que tal fato supõe e gera, os autores, por sua parte, preferem explorar a capacidade que a língua possui de definir e de ocasionar outras percepções do real. A emancipação do diálogo no que diz respeito a seus enunciadores confronta $\mathrm{o}$ espectador com mundos onde tanto o sentido quanto as identidades não são mais dados, mas precisam ser construídos, dentro da interação verbal e dos espaços de indeterminação causada pelas escritas. Neste sentido, o estado de "carência" do personagem é sobretudo um apelo à participação do espectador no processo de [construir] 
sentido: abre um espaço dialógico que o envolve na constituição de outros círculos de referências, e lembra a ele que a pessoa, longe de ser algo pronto, é sempre um dado em potencial. 